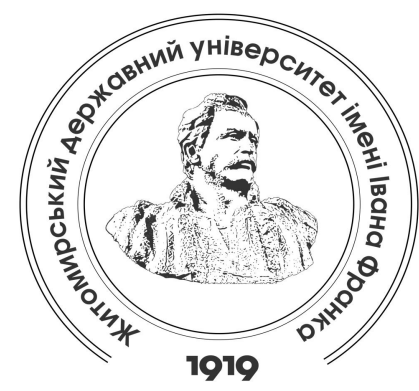

Zhytomyr Ivan Franko State University Journal. Pedagogical Sciences. Vol. 2(97)

Вісник Житомирського державного університету імені Івана Франка.

Педагогічні науки. Вип. 2 (97)

ISSN (Print): 2663-6387

ISSN (Online): 2664-0155

UDC [378.147:373.3.011.3-051]:004

DOI 10.35433/pedagogy.2(97).2019.43-50

\title{
MEASURING THE DIGITAL COMPETENCE OF FUTURE PRIMARY SCHOOL TEACHERS
}

\section{O. Hrynko*}

Reforming the education system in Ukraine dictates changes in the training of future primary school teachers. This is particularly relevant when the formation of the digital competence of future educators is considered. The research highlights the results of theoretical and empirical study concerning the diagnostics and measurement of students' digital competence: the definition of criteria, indicators and description of levels of its formation. The author identifies digital competence as a crucial component of the professional competence that combines the ability to use digital technologies to create effective teaching and learning process, critically evaluate digital resources in terms of expediency of their application in professional activities, and acquire technological innovations. In view of this, four groups of criteria and indicators have been established regarding the acquisition of digital technology ability: the development of students' cognitive skills; the development of students' creative skills; the development of student's communicative skills; the development of students' collaborative skills. Based on these developed criteria and indicators, the author characterizes the three levels of the formation of the digital competence of the future primary school teacher as: high (student strives for self-development, creatively solves the tasks, organizes a mutual work, helps other participants), adequate (student uses the offered digital technologies and improves the ability to work with already known tools, solves the tasks using the given recommendations, follows ethical principals in the course of network communication, responsibly treats a group work), low (student does not feel an inner need for self-development via the usage of digital technologies, has no own ideas, has few or none participation in mutual work, strives to do the work separately from the group).

Key words: higher education, future primary school teacher, digital competence, cognitive skills, creative skills, communicative skills, collaborative skills, criteria, indicators, levels.

\footnotetext{
${ }^{*}$ Candidate of Psychological Sciences, Associate Professor (Donbas State Pedagogical University, Sloviansk)

Grinko2703@gmail.com

ORCID: 0000-0001-9834-7181
} 


\section{ДІАГНОСТИКА ЦИФРОВОЇ КОМПЕТЕНТНОСТІ МАЙБУТНІХ УЧИТЕАІВ ПОЧАТКОВОЇ ШКОАИ}

\section{В. О. Гринько}

Реформування системи освіти в Украйні диктуе зміни й у професійній підготовиі майбутніх учителів початкової школи, зокрема актуальності набуває формування иифрової компетентності майбутніх педагогів. Дослідження висвітлюе результати теоретичних та емпіричних пошуків з проблеми діагностики і вимірювання иирровоі компетентності студентів: визначення критеріїв, показників та опис рівнів ї сформованості. Авторка трактуе иифрову компетентність як компонент професійної компетентності, шо поєднуе уміння використовувати иифрові технології для створення ефективного навчально-виховного процесу, критично оцінювати ииррові ресурси в аспекті доиільності їх застосування у професійній діяльності, оволодівати технологічними інноваціями. 3 огляду на ие, обтрунтовано чотири групи критеріїв $i$ показників сорормованості умінь використовувати иифрові технологї̈: для розвитку когнітивних умінь студентів; для розвитку креативних умінь студентів; для розвитку комунікативних умінь студентів; для розвитку колаборативних умінь студентів. Спираючись на розроблені критерії та показники, авторка характеризує три рівні сорормованості иифрової компетентності майбутнього вчителя початкової школи: високий (студент прагне до саморозвитку, креативно вирішуе завдання, організовуе спільну роботу, допомагае іншим учасникам), достатній (студент використовує пропоновані иифрові технології та вдосконалюе уміння роботи з вже відомими інструментами, вирішуе завдання, використовуючи надані рекомендації, дотримується етики в ході мережного спілкування, відповідально ставиться до групової роботи), низький (студент не відчуває внутрішньої потреби у саморозвитку иляхом використання иифррових технологій, не має власних ідей, майже або зовсім не бере участі в груповій роботі, прагне зробити роботу окремо від групи).

Ключові слова: вища освіта, майбутній учитель початкової школи, иифрова компетентність, когнітивні уміння, креативні уміння, комунікативні уміння, колаборативні уміння, критерії, показники, рівні.

Introduction. The constantly changing modern world is characterized by the daily information updating. It is a necessity that teachers follow innovations, not only within the pedagogical sciences, but more generally within different fields to remain familiar with the latest trends and developments. Education reform tends to focus teachers' attention on continual professional development in order to meet dynamic environment demands.

The modern development trends of social, cultural and informational aspects of future teachers' professional training necessitate special consideration within the context of country-specific study. This is reflected in the legal normative documents that outline the education policy priorities of Ukraine:

"The strategy of information society development in Ukraine" (2013), The Law of Ukraine "On Higher Education" (2014), The Project "Digital Agenda for Ukraine" (2016), The Draft Law of Ukraine "On National Program of Informatization" (2017), etc.

Thus, the formation of digital competence is one of priority directions within the future teachers' professional development. Digital competence combines the ability to use various information instruments (computers, functions and capacities of software, options of local and global computer networks, etc.), as well as the expertise to employ these instruments efficiently within pedagogical activity. A high level 
of primary school teachers' digital competence is becoming an indicator that effective information and communication technologies are being employment by educational institutions. This indicates the success of education establishments' activity and serves as a necessary prerequisite for the improvement of staff's professional potential.

The analysis of main researches and publications. A great number of scholars in the field of information technologies are interested in the particulars of future teachers' digital competence formation.

The theoretical basis of the competence approach in education is covered by a number of scientists, namely N. Bibik, S. Bondar, M. Zhaldak, V. Kukharenko, O. Ovcharuk, O. Pometun, O. Spirin and others.

The methodology of teachers' digital competence formation and evaluation is represented in the papers written by both native and foreign scholars: O. Barny, V. Bykova, V. Vember, O. Kuzminska, M. Leshchenko, N. Morze, L. Tymchuk, M. Fraile, A. Peñalva-Vélez, Maria Spante, Mona Lundin and others. In 2006, the European Commission published a study entitled "Digital Competence in Practice: An Analysis of Frameworks"). Within this study, it is noted that the digital competence realizes an ability to employ information and communication technologies critically and creatively in order to attain goals in the field of work, education, leisure time and social activity. Digital activity is included in the list of key lifelong learning competencies in European countries [2].

The united research center scholars of the European Commission developed a European system of digital competence on the basis of consultations and active cooperation with a wide range of stakeholders from areas such as industry, education, staff training, employment, social partnership, etc. C. Redecker and Y. Punie designed a framework of teachers' digital competence (DigCompEdu). The necessary instruments of teachers' IT competence improvement are outlined in the European system of teachers' digital competence. The system DigCompEdu was created to implement a common approach concerning the identification of the main spheres of teachers' digital competence in the European countries [7].

A. Ferrari interprets digital competence as a set of knowledge, abilities, and approaches that are essential to employ information and communication technologies, digital media so as to exercise tasks; solve problems; communication; information management; cooperation; creation and content expansion; knowledge construction on the basis of effectiveness, propriety, criticism, creativity, independence, flexibility, ethics, reflectivity for professional activity, education, rest, mutual work, meeting consumer demands and provision of opportunities for the rights realization [3].

A similar interpretation concerning understanding information and digital competencies can also be found within "The New Ukrainian School" [5]. The New Ukrainian School embraces "sure and at the same time critical use of information and communication technologies (ICT) to create, search, process and exchange information at work, within public space and private communication; information and media literacy, basics of programming, algorithmic thinking, work with databases, security skills in Internet and cybersecurity; understanding of professional ethics (copyright, intellectual property etc.)" [5: 11].

The outline of unresolved issues brought up in the article. 
Summing up scholar's views on the essence of teachers' digital competence, as well as taking into account the particulars of future primary school teachers' training, one may define digital competence in the following terms: as a component of modern teacher professional competence that combines the abilities to employ digital technologies in creating effective and cognitive teaching and educational processes for pupils, as well as critically evaluating whether digital resources are credibly for professional activity. It should be noted that the development of diagnostic tools is rather important to effective digital competence formation, including the identification of criteria and levels of formation.

The formulation of the article aims and tasks. The research aim is to determine criteria and relative indicators of future primary school teachers' digital competence formation.

Results and Discussion. The evaluation of the effectiveness of digital technologies within the author's methodological system was carried out through the identified criteria and indicators of future teachers' digital competence. It is students' ability to employ digital technologies and develop skills of the $21^{\text {st }}$ century, particularly cognitive, creative, communicative and collaborative expertise.

During the course of the pedagogical diagnose research (2014 - 2016), conducted at the university department with 90 student participants, the following criterion groups were determined: indicators of the ability formation of digital technology skills to develop students' cognitive skills; indicators of the ability formation of digital technology skills to develop students' creative skills; indicators of the ability formation of digital technology skills to cultivate students' collaborative skills. The criteria and indicators of each group will be characterized separately.
Indicators of the ability formation of digital technology skills to develop students' cognitive skills

1) cognitive and projective criterion:

- practicability understanding of task solving;

- ability to find information necessary for task implementation;

- ability to reason a sequence of actions for task implementation.

2) cognitive and technological literacy criterion:

- knowledge of digital technology options as a means of cognitive ability development;

- expertise to choose technology that corresponds to task particulars;

- ability to deepen knowledge about new digital technologies and opportunities of their usage to stimulate students' cognitive development.

3) cognitive and prognostic criterion:

- ability to evaluate a cognitive activity on the basis of digital technology usage from the perspectives of their realization in the further pedagogical activity;

ability to evaluate critically statements and remarks concerning the usage of digital technology for the stimulation of cognitive development;

- ability to predict further cognitive development on the basis of digital technology usage.

Criteria and indicators of the
ability formation of digital
technology skills to develop
students' creative skills.

1) creative and projective criterion: creative task understanding;

- ability to find information necessary for creative intention implementation;

- ability to create an example of a creative activity relevant to a stated educational aim

2) creative and technological literacy criterion: 
- knowledge of digital technology options for creative abilities development;

- ability to choose the technology that corresponds to the particulars of a creative activity;

- ability to deepen knowledge of digital technology and usage options within creative activity.

3) creative and prognostic criterion:

- ability to evaluate creative activity on the basis of digital technology usage within the context of pedagogical activity;

- ability to evaluate critically statements and remarks concerning the usage of digital technology for the stimulation of creative development;

- ability to predict further creative development on the basis of digital technology usage.

Criteria and indicators of the ability formation of digital technology skills to develop students' communicative skills.

1) communicative and projective criterion:

- communicative

task

understanding;

- ability to find information

necessary for communicative task implementation;

- ability to carry out a set of measures for communicative task implementation.

2) communicative and technological literacy criterion:

- knowledge of digital technology options for communicative development stimulation;

- ability to choose technology that corresponds to the particulars of communicative activity;

- ability to deepen knowledge of digital technology and usage options for communicative development

stimulation.

3) communicative and procedural criterion:

- ability to use technology for the perception and reproduction of information messages in the process of communication with other people;

ability to use technology for participation in discussions, defending personal point of view, etc.;

- ability to follow ethical practices in the course of online communication.

Criteria and indicators of the ability formation of digital technology skills to develop students' collaborative skills.

1) collaborative and projective criterion:

- collaborative task understanding;

- ability to find information

necessary for task implementation;

- ability to reason a sequence of actions for collaborative task implementation.

2) collaborative and technological literacy criterion:

- knowledge of digital technology options for the stimulation of collaborative skills development;

- ability to choose technology that corresponds to the particulars of collaborative activity;

- ability to deepen knowledge of new digital technology and usage options in collaborative activity.

3) collaborative and procedural criterion:

- ability to use digital technology for the implementation of collaborative interaction in the course of task fulfillment;

- ability to discuss content quality directly or online, evaluating critically statements and remarks in regard to a created product;

- ability to maintain a positive and supportive atmosphere during collaborative activity.

During the course of future primary school teachers' training, it is necessary to define the levels of digital technology skill formation for the development of $21^{\text {st }}$ century skills on the basis of developed criteria. 


\section{Characterization of high, adequate and low-level digital technology skills are as follows:}

- a high level is a conscious and responsible approach to task implementation, ability to find necessary information and problem solutions without assistance, composing a plan of action and predict a result, aspiring to deepen knowledge on one's own, striving for selfdevelopment, improvement of skills and deepening knowledge regarding work with previously familiar instruments, an analysis of their usage when carrying out tasks; solving tasks creatively, considering a few variants of any plan, scrutinizing proposed digital technologies and willingness to try other variants to realize ideas in a better way; ability to employ digital technology for communication, expressing an opinion in the information space clearly and briefly, ability to ask questions correctly and reason the usage of particular digital technologies, following ethical principles in the course of online communication; ability to use digital technology for mutual work actively, ability to distribute work among all group members and accept personal responsibility for executed tasks, having a respectful attitude to all project / task participants, ability to take into account the opinion of others, showing interest in the positive results of group work, helping other stakeholders and creating a positive working atmosphere;

- an adequate level is a conscious and responsible approach to task implementation, the presence of motivation to acquire new knowledge and technologies, finding different problem solution variants, using proposed digital technologies and improvement of work with the familiar instruments; executing tasks creatively using recommendations, regarding digital technologies critically and trying other variants to carry out ideas in a better way; ability to employ digital technologies for communication, ability to express an opinion in the information space clearly and briefly, ability to ask questions correctly and reason the usage of particular digital technologies, following ethical principles in the course of online communication; ability to use digital technology for mutual work, a respectful attitude to group work, ability to accept responsibility for tasks, a respectful attitude to all project / task participants, ability to take into account the opinion of others;

a low level is an inadequate understanding of the reasoning of digital technology employment within a specific task. It embodies indifference in the search of new solutions and does not comprehend the influence of digital technology on personal development; it lacks an inner need to engage in selfdevelopment via the usage of digital technology; there is an absence of personal ideas when employing training material; avoiding group discussions in information space, inability to explain the reasoning of certain technology usage, violations of net ethics; identification of inertness and indifference when distributing roles for group work assignments, aspiration to do work outside of group.

Conclusions. The article deals with the topical problem of future primary school teachers' training, in particular the diagnostics of students' digital competence expertise on the basis of determined criteria and relative indicators during experimental research. In addition, the identification of four criterion groups made it possible to carry out monitoring of students' abilities to employ digital technologies to develop cognitive, creative, communicative and collaborative skills. A proper level of these students' competences enables a successful life and effective professional activity in the 
$21^{\text {st }}$ century. The diagnostic instruments included:

- criteria and indicators of abilities formation to use digital technology for the development of students' cognitive skills;

- criteria and indicators of abilities formation to use digital technology for the development of students' creative skills;

- criteria and indicators of abilities formation to use digital technology for the development of students' communicative skills;

- criteria and indicators of abilities formation to use digital technology for the development of students' collaborative skills.

The three levels of primary school future teachers' digital competence were developed on the basis of determined criteria and relative indicators. They include high, adequate and low levels.

The perspectives for further research lie in the analysis of processes and results in the experimental stage regarding the improvement of future primary school teachers' digital competence formation for the development of their cognitive, creative, communicative and collaborative abilities.

\section{REFERENCES (TRANSLATED \& TRANSLITERATED)}

1. Balyk, N.R., Schmyher, G.P. (2018). Metodologiia formuvannia tsyfrovykh kompetentnostei u konteksti rozrobky tsyfrovogo kontentu [Methodology of digital competence formation in the context of digital content development]. Fizykomatematychna osvita - Physical and mathematical education, 2(16), 8-12. Retrieved from http://fmojournal.fizmatsspu.sumy.ua/journals / 2 018-v2-16/2018_2-16-

Balyk_Shmyher_FMO.pdf

DOI
10.31110 / 2413-1571-2018-016-2001 [in Ukrainian].

2. European

Union.

Recommendation of the European Parliament and to the Council of 18 December 2006 on key competences for lifelong learning (2006/962/EC). Official Journal of the European Union, $2006 . \quad$ Retrieved from http:/ / eurlex.europa.eu/LexUriServ/Le xUriServ.do?uri=OJ:L:2006:394:0010:0 018:EN:PDF [in English].

3. Ferrari, A. Digital (2012). Competence in Practice: An Analysis of Frameworks. Luxemburg: IPTS-JRC. Retrieved from http://ftp.jrc.es/EURdoc/JRC681 16.pdf DOI: 10.2791/82116 [in English].

4. Grabovskiy, P.P. (2015). Kryterii, pokaznyky i rivni rozvytku informatsiinoi kompetentnosti vchytelia pryrodnycho-matematychnykh

predmetiv [The criteria, indexes and levels of teacher's of natural and mathematics subjects information competence development]. Informatsiini tekhnolohii $v$ osviti - Information technologies in education, 24, 134-146. Retrieved

http://ite.kspu.edu/en/node/2468

DOI $10.14308 /$ ite000556 [in Ukrainian].

5. Nova ukrainska shkola: kontseptualni zasady reformuvannia zahalnoi shkoly [New Ukrainian School: Conceptual Principles for Reforming the General School]. (2017). Retrieved from http://nus.org.ua/wp-

content/uploads/2017/07/konczepcziy a.pdf [in Ukrainian].

6. Romanovskyi, O.H., Grineva, V.M., Zhernovnykova, O.A., Shtefan, L.A., Fazan, V.V. (2018). Formuvannia tsyfrovoi kompetentnosti maibutnikh uchyteliv matematyky: konstatuvalnyi etap [Formation of prospective mathematics teachers' digital competence: ascertain stage]. Informatsiini tekhnolohii $i$ zasoby navchannia - Information Technologies and Methods of Education, 3, 184-200. 
Retrieved

from

https://journal.iitta.gov.ua/index.php/

itlt/article/view/2412.

$10.33407 /$ itlt.v65i3.2412

DOI:

Ukrainian].

7. Vuorikari, R., Punie, Y., Carretero

Gomez S., Van den Brande, G. (2016).
DigComp 2.0: The Digital Competence Framework for Citizens. Update Phase 1: The Conceptual Reference Model. Luxembourg Publication Office of the European Union. EUR 27948 EN. DOI:10.2791/11517 [in English].

Received: March 27, 2019

Accepted: June 03, 2019 